\title{
Treatment of Rectocutaneous Fistulae Caused by Bite Wound in a Cat
}

\author{
Fatma GÖRÜCÜ1*, Yusuf KOÇ${ }^{1}$, Musa KORKMAZ ${ }^{1}$, Zülfükar Kadir SARITAŞ ${ }^{1}$ \\ *1 Afyon Kocatepe University, Faculty of Veterinary Medicine, Surgery Department, 03200, Afyonkarahisar, Turkey
}

\begin{abstract}
Recto-cutaneous fistulas, which are common in humans, rarely occur in companion animals. In this case report, we aimed to provide information to our colleagues about the diagnosis and treatment of recto-cutaneous fistula in a cat. A one and a half months old British shorthair kitten, weighing $600 \mathrm{~g}$, was brought to Afyon Kocatepe University Veterinary Health Application and Research Center Surgery Clinic by its owner because of an open wound on the side of the tail for a week, and feces coming from this wound. Recto-cutaneous fistula was diagnosed on clinical examination. Under general anesthesia, the defect was sutured with simple pattern. Since the skin sutures were opened, the wound was treated with rifamiycine, nitrofurazone ointment and bephanthene cream after irrigation with rivanol \%0.1. In conclusion, recto-cutaneous fistula, which is the most important complication of rectal perforation for any reason, is rarely seen in cats and dogs. Accurate diagnosis and treatment are important for rapid recovery.
\end{abstract}

Keywords: Cat, bite wound, recto-cutaneous fistula

\author{
$* * *$ \\ Bir Kedide Isırık Yarası Kaynaklı Rektokutanöz Fistül Tedavisi \\ ÖZ
}

\begin{abstract}
İnsanlarda sıklıkla görülen rektokutanöz fistüller, evcil hayvanlarda nadiren ortaya çıkar. Bu olgu sunumunda, yavru bir kedide karşılaşın rektokutanöz fistül olgusunun tanı ve tedavisi hakkında klinisyen meslektaşlarımıza bilgi vermek amaçlanmıştır. Biritish shorthair 1rk1 1,5 aylık 600 gr ağrllığındaki bir kedi, kuyruğunun yanında içinden dışkı gelen bir yara şikayetiyle Afyon Kocatepe Üniversitesi Veteriner Sağlık Uygulama ve Araştırma Merkezine getirildi. Klinik muayene yapılarak rektokunatöz fistül tanısı konuldu. Genel anestezi altında rektumdaki defekt belirlendi ve basit ayrı dikiş uygulaması yapılarak kapatıldı. Deri dikişleri açıldığı için \%0,1'lik rivanol ile irrigasyon sağlandıktan sonra rifamisin ampul, furasin pomad ve bepanten krem ile yara tedavisi yapıldı. Sonuç olarak, herhangi bir sebeple oluşan rektum perforasyonunun en önemli komplikasyonu olan rektokutanöz fistül kedi ve köpeklerde nadiren görülen bir durumdur. Doğru teşhis ve tedavi iyileşmenin hızlı şekillenmesinde önemlidir.
\end{abstract}

Anahtar kelimeler: Kedi, 1sırık yarası, rektokutanöz fistül

To cite this article: Görücü F. Koç Y. Korkmaz. M. Sartaş Z.K. Treatment of Rectocutaneous Fistulae Caused by Bite Wound in A Cat

Kocatepe Vet J. (2021) 14(4): 525-527

Submission: 25.08.2021 Accepted: 16.11.2021 Published Online: 17.11.2021

ORCID ID; FG: 0000-0001-7630-0788, YK: 0000-0002-6342-5466, MK: 0000-0002-7646-0009, ZKS: 0000-0002-7659-6635

*Corresponding author e-mail: fatmagorucu@gmail.com 


\section{INTRODUCTION}

A fistula is defined as an abnormal connection in the form of a canal between two epithelial-layered surfaces. Gastrointestinal fistulas can be congenital or acquired, and they can form between the intestine and another organ or skin (Pickhardt et al. 2002).

Perirectal abscesses and fistulas are common in humans, but similar conditions are rarely seen in animals (Lojszczyk-Szczepaniak et al. 2014). Enterocutaneous fistulas are pathological tunnels between the intestines and the skin, usually occur in large animals due to complications of umbilical hernia or their treatment (Byeon et al. 2008). Enterocutaneous fistulas are rarely encountered pathologies in small animals (Tsioli et al. 2009).

Rectal perforations and recto-cutaneous fistulas can be difficult to treat, sometimes despite early diagnosis and treatment, as they are prone to complications such as dehiscence, infection, and delayed healing. In dogs and cats, rectal perforation has been described most often in association with pelvic fractures. Overall, rectal tears are very rare $(<1 \%)$ in cases of pelvic trauma, and urethral or bladder perforation is more common in dogs with pelvic fractures. Other causes of rectal perforation include penetrating bite wounds, perineal herniorrhaphy or anal sacculectomy, trauma from swallowed foreign bodies or intraluminal foreign bodies entering through the anus, iatrogenic tears during rectal examination, misuse of enema tubes, gunshot injuries, abscesses at the base of the tail, and rectal perforation. stab wounds can be counted (Kılıç and Yaygingül, 2010). Recto-cutaneous fistula is a potential complication of any rectal perforation, including perianal surgery. Most rectal perforations described in dogs and cats occur in the most caudal $4 \mathrm{~cm}$ of the rectum (Muir 1998; Byeon et al. 2008; Frasson 2008; Łojszczyk-Szczepaniak et al. 2014).

Its clinical manifestations are drainage of feces from the fistula through the perianal defect and pain and swelling at the mouth of the fistula due to an inflammatory reaction. Diagnosis of recto-cutaneous fistula in dogs and cats is easily made by drainage of feces and detection of fecal contamination of the area (Frasson 2008).

In this case report, we aimed to provide information to our colleagues about the diagnosis and treatment of recto-cutaneous fistula in a cat.

\section{CASE HISTORY}

A one and a half months old British shorthair kitten, weighing $600 \mathrm{~g}$, was brought to Afyon Kocatepe University Veterinary Health Application and Research Center Surgery Clinic by its owner because of an open wound on the side of the tail for a week, and feces coming from this wound. In the anamnesis taken from the patient's owner, it was learned that he had been taken to another clinic before and the wound was treated, but the healing did not occur.

As a result of the physical examination, an infected wound was seen on the craniolateral part of the anus. A thermometer was advanced from the anus and perforation of the rectum was determined and a diagnosis of recto-cutaneous fistula was made. In the present case, it was understood that the rectocutaneous fistula was formed as a result of abscess due to the bite wound. The animal was anesthetized with medetomidine $\mathrm{HCl}(40 \mathrm{mcg} / \mathrm{kg}$, IM, Domitor, Zoetis) and ketamine $\mathrm{HCl}(5 \mathrm{mg} / \mathrm{kg}$, IM, Ketasol, Richer pharma), after providing asepsis-antisepsis, the defect in the rectum was determined and a simple separate sutured with polydioxanone (PDS, 4/ 0), and an appropriately sized tube lubricated with vaseline was inserted into the rectum (Muir 1998). The skin was closed routinely with non-absorbable suture material propylene (Prolene, 4/0). A penrous drain was placed in the wound. In the postoperative period, cefdinir suspension $(10 \mathrm{mg} / \mathrm{kg}$, PO, Cempes, Sanovel) was prescribed twice a day for 7 days. Two days later, the drain and tube in the rectum were removed. Since the skin sutures were opened, the wound was treated with rifamiycine (Rif ampoule 125 mg, Koçak Farma), nitrofurazone ointment (Furacin pomade, Sanofi İlaç) Dexpanthenol (Bephanthen cream, Bayer) after irrigation with ethacridine lactate $\% 0.1$ (Rivanol toz $1 \mathrm{~g}$, İstanbul İlaç). After 14 days the animal had fully recovered (Fig. 1). 

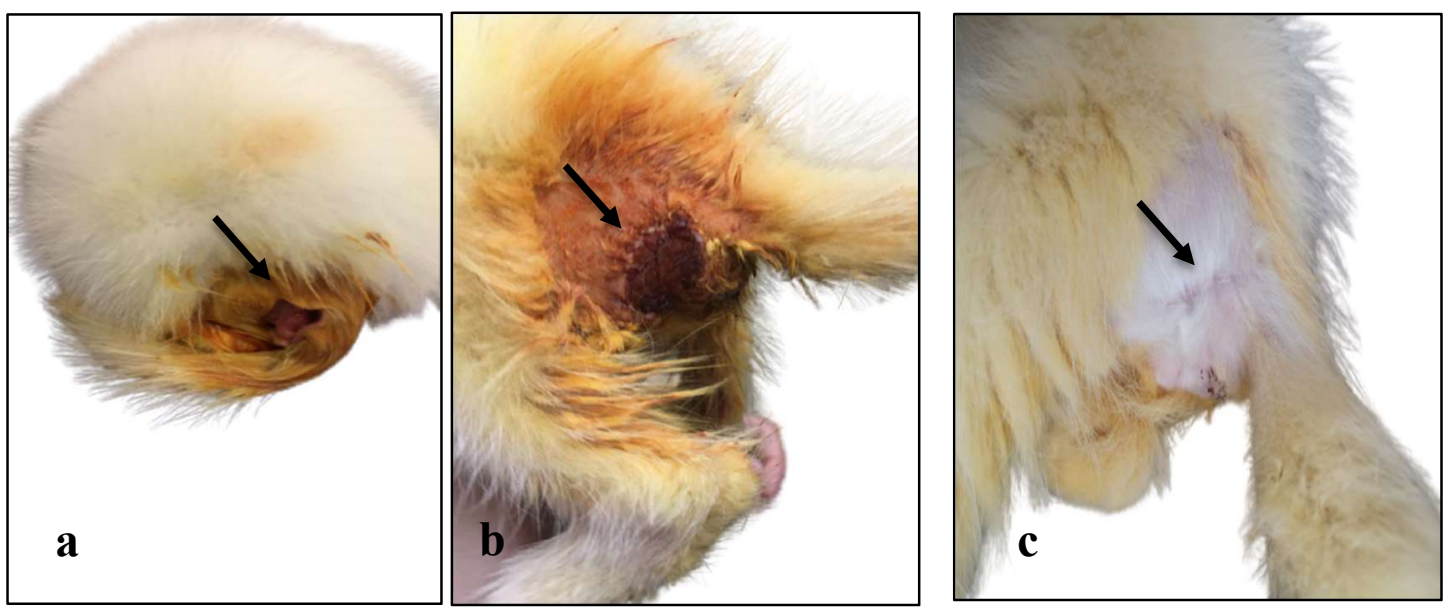

Figure 1: a. Rectocutaneous fistula (black arrow), b. Clinical appearance of the wound on Postoperative $7^{\text {th }}$ day (black arrow), c. Complete recovery of the wound on Postoperative 14th day (black arrow).

Resim 1: a. Rektokutanöz fistül (siyah ok), b. Postoperatif 7. gündeki yaranın klinik görünümü (siyah ok), c. Postoperatif 14. gündeki tam iyileşme (siyah ok).

\section{DISCUSSION and CONCLUSSION}

Rectal perforations in cats and dogs usually occur as a result of fractures in the pelvis (Tsioli et al. 2009). Recto-cutaneous fistulas are one of the rare pathologies in cats (Kılıç and Yayıngül 2010).

In this case, the recto-cutaneous fistula in the kitten was formed as a result of abscess caused by the bite wound. Bite wounds are involved in the etiology of recto-cutaneous fistula and are consistent with literature data (Muir 1998).

Diagnosis is quite easy with stool draining from the fistula through the perineal defect and clinical signs such as pain and swelling at the mouth of the fistula. In the present case, feces were seen coming from the defect located on the craniolateral side of the anus and a diagnosis of recto-cutaneous fistula was made (Frasson 2008).

K1liç and Yayıngül (2010) conservatively treated a recto-cutaneous fistula associated with anal sac surgery in a cat. In our case, the defect in the rectum was repaired with operative intervention and the skin was closed routinely. Two days later, the skin wound was closed with second degree healing as the stitches on the skin were opened. There was no complication related to the fistula in the control performed three months later.

In conclusion, recto-cutaneous fistula, which is the most important complication of rectal perforation for any reason, is rarely seen in cats and dogs. Accurate diagnosis and treatment are important for rapid recovery.

Conflict of Interest: The authors declared that there is no conflict of interest.
Ethical Approval: This study is not subject to the permission of HADYEK in accordance with the "Regulation on Working Procedures and Principles of Animal Experiments Ethics Committees" 8 (k). The data, information and documents presented in this article were obtained within the framework of academic and ethical rules.

\section{REFERENCES}

Byeon YE, Park SS, Choi MC, Kweon OK, Kim WH. Enterocutaneous fistula as a result of chronic bite wound repair in a dog. J Vet Med Sci. 2008; 70(11):1281-1283.

Fransson BA. Rectocutaneous fistulas. Compendium On Continuing Education For The Practising VeterinarianNorth American Edition. 2008; 30(4):224.

Kilic N, Yaygıngül R. Rectocutaneous Fistula in A Cat: A Case Report. Kafkas Univ Vet Fak. 2010; 16(4):681-683.

Lojszczyk-Szczepaniak A, Komsta R, Dębiak P, Barbara L. Radiological diagnosis of rectocutaneous fistulas in a cat-a case report. Acta Vet Brno. 2014; 83(3):255-259.

Muir P. Rectal perforation associated with pelvic fracture in a cat. Vet Rec. 1998; 142(14):371-372.

Pickhardt PJ, Bhalla S, Balfe DM. Acquired gastrointestinal fistulas: classification, etiologies, and imaging evaluation. Radiol. 2002; 224(1):9-23.

Tsioli V, Papazoglou LG, Anagnostou T, Kouti V, Papadopoulou P. Use of a temporary incontinent endon colostomy in a cat for the management of rectocutaneous fistulas associated with atresia ani. J Feline Med Surg. 2009; 11(12):1011-1014. 